\title{
FAKTOR-FAKTOR YANG BERHUBUNGAN DENGAN KEJADIAN BULLYING PADA ANAK KELAS IV, V, DAN VI SD, DI SD X KOTA PADANG
}

\author{
Lola Felnanda Amri ${ }^{1}$ \\ Politeknik Kesehatan Kemenkes Padang \\ Email: \\ Zulharmaswita2 \\ Politeknik Kesehatan Kemenkes Padang \\ Email:
}

\begin{abstract}
Abstrak - Perilaku kekerasan antar siswa disekolah akhir - akhir ini semakin meningkat. Perilaku kekerasan yang ditampilkan tidak hanya dilakukan oleh peserta didik tingkat SMA dan SMP, bahkan di tingkat SD pun sudah banyak terjadi. Perilaku kekerasan antar siswa ini lebih dikenal dengan nama Bullying. Tujuan penelitian ini untuk mengetahui faktor-faktor yang berhubungan dengan kejadian Bullying Pada Anak Kelas IV, V, Dan VI SD, Di SD X Kota Padang. Rancangan penelitian ini adalah penelitian kuantitatif yang menggunakan desain penelitian deskriptif korelasi dengan pendekatan cross sectional dengan sampel penelitian sebanyak 129 siswa dengan metode proportional sampling. Data dianalisis dengan menggunakan uji statistik Chi Square dan analisis regresi logistik ganda. Hasil analisis penelitian menunjukkan variabel yang paling besar pengaruhnya terhadap kejadian Bullying adalah faktor lingkungan dengan $\mathrm{P}$ Value $0,073(\mathrm{OR}=4,092)$ dan dapat diartikan bahwa jika siswa SD terpapar faktor lingkungan yang beresiko Bullying sebanyak satu kali, maka siswa SD tersebut akan beresiko untuk berperilaku Bullying sebanyak 4 kali. Disarankan elemen pendidikan yang meliputi guru-guru dan perangkat sekolah, keluarga, siswa untuk memutus rantai kekerasan ini, sehingga bullying tidak dianggap sebagai hal yang lumrah dan dilakukan pembiaran terhadap perilaku ini.
\end{abstract}

Kata kunci: perilaku kekerasan; bullying; siswa

\section{Pendahuluan}

Perilaku kekerasan antar siswa disekolah akhir akhir ini semakin meningkat. Hal ini ditandai dengan banyaknya pemberitaan tentang kejadian perilaku kekerasan tersebut di media cetak, televisi bahkan media sosial. Perilaku kekerasan yang ditampilkan tidak hanya dilakukan oleh peserta didik tingkat SMA dan SMP, bahkan di tingkat SD pun sudah banyak terjadi. Perilaku kekerasan ini bisa berupa ancaman atau pemalakan, ejekan, menggertak, mengganggu, melecehkan dan lain sebagainya. Bentuk ancaman atau pemalakan biasanya lebih sering muncul seperti minta makanan, minta dibuatkan tugas, minta contekan disaat ujian. Perilaku lain yaitu berupa ejekan kepada teman-temannya hingga teman yang diejek menangis. Selain itu juga terjadi kebiasaan untuk memanggil temannya dengan nama orang tuanya atau bukan nama siswa yang sebenarnya dengan tujuan untuk melecehkan. Perilaku kekerasan antar siswa ini lebih dikenal dengan nama Bullying.

Bullying bisa dikatergorikan sebagai suatu perilaku yang agresif, bersifat merusak yang dilakukan dengan sengaja serta berulang-ulang yang bertujuan untuk merugikan korbannya bahkan bisa disertai dengan adanya perbedaan atau ketidak seimbangan kekuatan antara pelaku dan korban (National Crime Prevention Centre, 2008). Namie (2014) menyatakan bahwa Perilaku Bullying merupakan tindakan negatif yang dilakukan secara berulang oleh sebagian siswa atau lebih yang bersifat menyerang karena adanya ketidak seimbangan kekuatan antara pihak yang terlibat baik itu merupakan serangan emosional, verbal ataupun fisik seperti mengejek, menyebarkan gosip, menghasut, menindas, menakut-nakuti (mengintimidasi), memberikan mengancam, mengucilkan, memalak atau menyerang secara fisik seperti mendorong, menampar, atau memukul.

Prevalensi bullying di sekolah yang terjadi di beberapa negara Eropa, Amerika serta Asia diperkirakan sekitar 8\%-50\% (Soedjatmiko dkk, 2011 dalam Diyantini, Yanti dan Lismawati, 2015). Dake, Price dan Telljohann (2003), menyatakan bahwa perilaku bullying umumnya terjadi di sekolah dasar (SD) yaitu 11,3\%-49,8\%. Sementara di Indonesia, berdasarkan data KPAI dari tahun 2011 hingga bulan Agustus tahun 2014, terdapat 369 pengaduan terkait masalah perilaku ini dimana $25 \%$ nya adalah di bidang pendidikan (Setyawan, KPAI, 2014). Data KPAI juga menyebutkan bahwa $87,6 \%$ anak mengaku pernah mengalami kekerasan di lingkungan sekolah dalam berbagai bentuk, dimana $29,9 \%$ dari kekerasan tersebut dilakukan oleh guru, $42,1 \%$ dilakukan oleh teman sekelas, dan 28\% dilakukan oleh teman lain kelas (Prima, 2012, dalam Latifah, 2012).

Hasil pengamatan yang dilakukan pada siswa SD $\mathrm{X}$ kota padang, ditemukan bahwa salah seorang siswi menjadi ketua kelas serta yang diberi wewenang oleh guru untuk menggumpulkan nama - nama peminat 
kegiatan Eskul Pramuka melakukan intimidasi pada beberapa siswa dan siswi yang tidak disukainya yaitu melarang seorang siswi ikut kegiatan pramuka dengan alasan "belum tentu kamu diperbolehkan untuk ikut pramuka oleh mama mu" sehingga siswi yang mau ikut pramuka tadi terpaksa batal mengikuti kegiatan eskul pramuka, di kesempatan lain siswi yang sama memarahi siswa lain tanpa alasan yang jelas sehingga siswa tersebut menangis. Di lain kesempatan disaat guru berhalangan hadir dan guru pengganti belum datang, siswi yang sama bersikap sebagai seorang guru di depan kelas dan memerintahkan teman-temannya untuk melakukan apa yang di suruhnya, bagi siswa/ siswi yang tidak mau mengikuti perintahnya, maka siswi tersebut akan mengeluarkan kata-kata ejekan hingga yang lain terpaksa menggikutinya. Walaupun penelitian tentang bullying ini sudah mulai banyak dilakukan namun melihat kondisi diatas, maka peneliti tertarik melakukan penelitian tentang "Faktor - Faktor yang berhubungan dengan kejadian Bullying Pada Anak Kelas IV, V, Dan VI SD, Di SD X Kota Padang" sehingga diharapkan perilaku Bullying ini bisa dikurangi atau bahkan dihindari agar anak-anak kita dapat memperoleh suasana belajar yang kondusif serta bisa lebih bebas berekspresi sehingga berprestasi dalam belajar dapat meningkat.

\section{METODE}

Penelitian ini adalah suatu penelitian yang bersifat kuantitatif yang menggunakan desain penelitian deskriptif korelasi dengan pendekatan cross sectional. Penelitian deskriptif korelasional bertujuan untuk menggambarkan hubungan antar variabel (Polit \& Beck, 2004). Pengukuran Variabel independennya adalah faktor individu, teman sebaya, dan faktor lingkungan; variabel dependennya adalah kejadian Bullying, serta faktor counfoundingnya adalah usia, jenis kelamin, kelas.

Peneliti mengambil siswa dan siswi kelas IV,V, dan VI SD di SD X Kota Padang sebagai responden dengan menggunakan teknik simple random sampling. Kriteria inklusi yang disyaratkan dalam penelitian ini adalah: siswa dan siswi sekolah dasar yang duduk dikelas IV,V, dan VI; sehat jasmani dan rohani; dan bersedia menjadi responden penelitian. Kriteria eksklusi dalam penelitian ini adalah: siswa dan siswi yang mengundurkan diri di tengah-tengah penelitian; dan siswa dan siswi yang tidak berada ditempat disaat penelitian dilakukan. Jumlah sampel yang memenuhi kriteria tersebut sebanyak 129 siswa. Pengumpulan data dilakukan dengan menggunakan instrumen dalam bentuk kuesioner mencakup informasi tentang individu, teman sebaya dan lingkungan; penyebab bullying; dan pelaku bullying.

Peneliti menggunakan analisis secara univariat, bivariat, dan multivariat. Analisi univariat dilakukan untuk data individu, teman sebaya dan lingkungan. Analisis bivariat digunakan untuk mengetahui hubungan faktor-faktor penyebab terjadinya Bullying dengan kejadian Bullying pada siswa SD dengan uji statistik Chi Square. Sementara untuk analisis multivariat penelitian ini menggunakan analisis regresi logistik ganda dengan model faktor resiko untuk menghubungkan faktor penyebab Bullying dengan kejadian Bullying dan juga untuk mengetahui variabel mana yang paling dominan berhubungan dengan kejadian Bullying. Analisis multivariat ini juga menganalisis hubungan antara variabel perancu (usia, jenis kelamin, dan kelas) dengan variabel dependen (kejadian Bullying).

\section{hasil \& Pembahasan}

\section{A. Hasil}

Hasil menunjukkan bahwa hampir separuh yaitu 38\% usia siswa SD X berada pada usia 11 tahun. Lebih dari separuh berjenis kelamin perempuan yaitu $59,7 \%$. Sebagian kecil yaitu 24\% memiliki geng di sekolah. Sementara dijelaskan bahwa hampir separuh yaitu 47,3\% siswa kelas IV,V,VI SD X Kota Padang Sumatera Barat mengalami kejadian Bullying. Pada Faktor Penyebab Kejadian Bullying didapatkan hasil bahwa sebagian kecil faktor individu menjadi penyebab periaku Bullying yaitu $18,6 \%$. Faktor teman sebaya yang menjadi penyebab Bullying hampir separuh yaitu 31\%. Faktor lingkungan yang menjadi penyebab Bullying adalah sebagian kecil yaitu $15,5 \%$.

Tabel 3.1

Distribusi Faktor Individu dengan Kejadian Bullying Pada Siswa Kelas IV,V, dan VI di SD X Kota Padang Sumatera Barat $(n=129)$

\begin{tabular}{|c|c|c|c|c|c|c|}
\hline \multirow{3}{*}{ Faktor Individu } & \multicolumn{4}{|c|}{ Bullying } & \multirow{2}{*}{\multicolumn{2}{|c|}{ Total }} \\
\hline & \multicolumn{2}{|c|}{ Ada Kejadian } & \multicolumn{2}{|c|}{$\begin{array}{c}\text { Tidak Ada } \\
\text { Kejadian }\end{array}$} & & \\
\hline & $\mathrm{n}$ & $\%$ & $\mathrm{~N}$ & $\%$ & $\mathrm{~N}$ & $\%$ \\
\hline Penyebab & 24 & 100 & 0 & 0 & 24 & 100 \\
\hline
\end{tabular}




\begin{tabular}{|c|c|c|c|c|c|c|c|c|c|}
\hline Bukan penyebab & 37 & 35,2 & 68 & 64,8 & 105 & 100 Faktor(D,ajgka, & 1,409 & 0,073 & 4,092 \\
\hline \multirow{2}{*}{ Jumlah } & \multirow{2}{*}{61} & \multirow{2}{*}{47,3} & \multirow{2}{*}{68} & \multirow{2}{*}{52,7} & \multirow{2}{*}{129} & Usia & 0,012 & 0,976 & 0,976 \\
\hline & & & & & & Jenis Kelamin & 0,597 & 0,183 & 0,183 \\
\hline Tabel $3.1 \mathrm{me}$ & & & & & & Kelas & 0.169 & 0,693 & 0,693 \\
\hline
\end{tabular}
siswa yang memiliki faktor individu sebagai penyebab kejadian Bullying.

Tabel 3.2

Distribusi Faktor Teman Sebaya dengan Kejadian Bullying Pada Siswa Kelas IV,V,VI di SD X Kota Padang Sumatera Barat $(\mathrm{n}=129)$

\begin{tabular}{lccccccc}
\hline \multirow{2}{*}{ Faktor Teman Sebaya } & \multicolumn{4}{c}{ Bullying } & \multirow{2}{*}{ Total } \\
\cline { 2 - 6 } & \multicolumn{4}{c}{ Ada Kejadian } & \multicolumn{2}{c}{$\begin{array}{c}\text { Tidak Ada } \\
\text { Kejadian }\end{array}$} & \\
\cline { 2 - 6 } & $\mathrm{n}$ & $\%$ & $\mathrm{n}$ & $\%$ & $\mathrm{~N}$ & $\%$ \\
\hline Penyebab & 27 & 67,5 & 13 & 32,5 & 40 & 100 \\
\hline Bukan Penyebab & 34 & 61,8 & 55 & 38,2 & 89 & 100 \\
\hline \multicolumn{1}{c}{ Jumlah } & 61 & 47,3 & 68 & 52,7 & 129 & 100 \\
\hline
\end{tabular}

Berdasarkan tabel 3.2 diperoleh bahwa ada sebanyak $67,5 \%$ siswa yang memiliki faktor teman sebaya sebagai penyebab kejadian Bullying.

\section{Tabel 3.3}

Distribusi Faktor Lingkungan dengan Kejadian Bullying Pada Siswa Kelas IV,V,VI di SD X Kota Padang Sumatera Barat $(n=129)$

\begin{tabular}{|c|c|c|c|c|c|c|}
\hline \multirow{3}{*}{ Faktor Lingkungan } & \multicolumn{4}{|c|}{ Bullying } & \multirow{2}{*}{\multicolumn{2}{|c|}{ Total }} \\
\hline & \multicolumn{2}{|c|}{ Ada Kejadian } & \multicolumn{2}{|c|}{$\begin{array}{ll}\text { Tidak } & \text { Ada } \\
\text { Kejadian } & \\
\end{array}$} & & \\
\hline & $\mathrm{n}$ & $\%$ & & $\%$ & $\mathrm{~N}$ & $\%$ \\
\hline Penyebab & 17 & 35 & & 15 & 20 & 100 \\
\hline Bukan Penyebab & 44 & 7,5 & & 32,5 & 109 & 100 \\
\hline Jumlah & 61 & 7,3 & & 52,7 & 129 & 100 \\
\hline \multicolumn{7}{|c|}{$\begin{array}{l}\text { Sesuai tabel } 3.3 \text { bahwa ada sebanyak } 85 \% \text { siswa } \\
\text { yang memiliki faktor lingkungan sebagai penyebab } \\
\text { kejadian Bullying. }\end{array}$} \\
\hline \multicolumn{7}{|c|}{$\begin{array}{c}\text { Hasil Pemodelan Multivariat Hubungan faktor } \\
\text { individu, faktor teman sebaya, dan faktor } \\
\text { lingkungan dengana kejadian Bullying di Pada } \\
\text { Siswa Kelas IV,V,VI di SD X Kota Padang } \\
\text { Sumatera Barat }\end{array}$} \\
\hline \multicolumn{2}{|c|}{ Variabel } & & & $\mathrm{p}$ & & \\
\hline \multicolumn{2}{|c|}{ Faktor Individu } & & & 0,998 & & \\
\hline $\begin{array}{l}\text { Faktor } \\
\text { Sebaya }\end{array}$ & Teman & & & 0,759 & & \\
\hline
\end{tabular}

Berdasarkan tabel 3.4 diperoleh hasil sebagai berikut yaitu: variabel yang paling besar pengaruhnya terhadap kejadian Bullying adalah faktor lingkungan dengan $\mathrm{P}$ Value 0,073 (OR = 4,092) dan dapat diartikan bahwa jika siswa SD terpapar faktor lingkungan yang beresiko Bullying sebanyak satu kali, maka siswa SD tersebut akan beresiko untuk befpłerilaku Bullying sebanyak 4 kali.

$\begin{array}{cc}3,360 & \\ (1,528-7,386) & 0,004\end{array}$

\section{B. Pembahasan}

Siswa kelas IV, V,dan VI SD X yang menjadi responden hampir separuh $(38 \%)$ berusia 11 tahun dan berjenis kelamin perempuan lebih dari separuh $(59,7 \%)$ dan sebagian kecil (24\%) memiliki geng di sekolah. Hal ini sejalan dengan hasil penelitian Diyantini, Yanti dan Lismawati (2015) yang menyatakan bahwa sebagian besar responden $(63,6 \%)$ berusia 11 tahun dan sebagian kecil lainnya berusia 10 tahun $(30,9 \%)$ dan 12 tahun (5,5\%). Begitu juga dengan penelitian yang dilakukan oleh Dewi (2014), yang menyatakan baRka ${ }^{95}$ lebih daxialusetengah $(52,7 \%)$ responden berusia 11 tahun. Namun hasil penelitian ini sedikit berbes/37 dari beberapa penelitian dimana responden

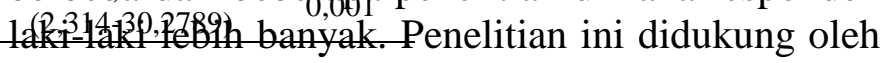
pendapat Offord, Boyle \& Racine (1991 yang dikutip oleh Bee (1994 dalam Siswati dan Widayanti, 2009)) yang menyatakan bahwa siswa usia 9-11 tahun, anak laki-laki menunjukkan peningkatan agresivitas dan dominasi dibandingkan siswi-siswi pada usia yang sama. Hasil analisis dari peneliti didapatkan bahwa terdapat perbedaan jenis kelamin siswa SD dalam berprilaku dimana laki-laki memiliki kekuatan yang lebih dibandingkan anak perempuan sehingga lebih cenderung untuk berprilaku agresif.

Sementara itu, melihat hasil siswa yang memiliki geng di sekolah, Latifah (2012) menyatakan bahwa responden yang memiliki kecenderungan berkelompok (memiliki geng) adalah sebesar $20 \%$ dari total responden. 
Berdasarkan hasil analisis dapat dinyatakan bahwa adanya kelompok siswa atau yang biasa disebut dengan geng, baik secara langsung maupun tidak langsung akan mempengaruhi perilaku siswa dalam bergaul dengan siswa yang lain. Hal ini bisa disebabkan karena adanya ikatan yang kuat didalam kelompok yang dapat menimbulkan tekanan bagi anak, serta akhirnya dapat memaksa anak untuk mengambil resiko, berperilaku melawan, dan menyebabkan timbulnya kekerasan (Wong, et all, 2009). Analisis peneliti ini juga didukung oleh pendapat Thompkin (2000, dalam Diyantini, Yanti dan Lismawati (2015); AASA, (2009), yang menyatakan bahwa adanya geng disekolah sering dikaitkan dengan peningkatan angka kekerasan di sekolah.

Sementara dijelaskan bahwa hampir separuh (47,3\%) siswa kelas IV,V,VI SD X Kota Padang Sumatera Barat mengalami kejadian Bullying. Latifah (2012), menyatakan bahwa kejadian Bullying pada anak sekolah dasar adalah sebesar $65 \%$. Dan penelitian yang dilakukan oleh Uba dan Juhari (2010 dalam Dewi, 2014), menyatakan kejadian Bullying sebesar 49,2\% dengan total sampel sebanyak 242 orang. Bullying telah dikenal sebagai masalah sosial yang terutama ditemukan dikalangan anak-anak sekolah. Hampir setiap anak mungkin pernah mengalami suatu bentuk perlakuan tidak menyenangkan dari anak lain yang lebih tua atau lebih kuat (Krahe, 2005 dalam Saifullah, 2016). Hasil penelitian ini didukung oleh pendapat Bukhim (2008 dalam Purwanto, 2010) yang mengatakan bahwa berbagai perilaku menyimpang yang dilakukan anak disebabkan oleh minimnya pemahaman anak terhadap nilai diri yang positif. Hasil analisis peneliti didapatkan bahwa kejadian bullying ini bisa terjadi disaat anak atau individu belum memiliki pemahaman moral yang positif dalam menilai dirinya sendiri sehingga mudah terombang ambing dalam bersikap, apalagi jika mendapat tekanan dari teman sebaya ataupun lingkungannya.

Pada faktor penyebab kejadian Bullying didapatkan hasil bahwa sebagian kecil $(18,6 \%)$ faktor individu, faktor teman sebaya yang menjadi penyebab Bullying hampir separuh $(31 \% 0$, dan faktor lingkungan sebagian kecil $(15,5) \%$. Ningrum dkk (2015), yang menyatakan bahwa faktor yang banyak mempengaruhi siswa untuk melakukan perilaku bullying di sekolah adalah faktor individu dan keluarga. Analisis peneliti didapatkan yaitu faktor penyebab kejadian bullying ini tidak hanya berasal dari dalam diri individu tersebut tetapi juga berasal dari luar diri individu terutama pengaruh dari lingkungan dan teman sebaya. Analisis peneliti ini didukung oleh pendapat AAOA (2009), yaitu yang merupakan faktor penyebab bullying adalah 1). Faktor individu; 2). Faktor teman sebaya; 3) Faktor Keluarga; 4). Faktor Lingkungan.

Sementara berdasarkan analisis hubungan faktor Individu dengan kejadian bullying di SD X ada sebanyak $100 \%$ siswa yang memiliki faktor individu sebagai penyebab kejadian Bullying, sebanyak $67,5 \%$ siswa yang memiliki faktor teman sebaya sebagai penyebab kejadian Bullying, dan sebanyak $85 \%$ siswa yang memiliki faktor lingkungan sebagai penyebab kejadian Bullying. Penelitian yang dilakukan oleh Ningrum dkk (2015), didapatkan bahwa faktor individu yang memungkinkan siswa menjadi seorang pelaku bullying adalah karena siswa sebelumnya merupakan korban bullying yang dilakukan oleh kakak kelas mereka. Sementara Soedjatmiko dkk (2013), menyatakan bahwa sekitar 60\% pelaku melakukan bullying pada teman sebaya. Sementara itu Magfirah dan Rachmawati (2009), yang menyatakan bahwa ada hubungan negatif yang sangat signifikan antara iklim sekolah dengan kecenderungan perilaku bullying. Semakin positif iklim sekolah, semakin rendah kecenderungan perilaku bullying, sebaliknya semakin negatif iklim sekolah, semakin tinggi kecenderungan perilaku bullying.

Analisis peneliti dan hasil observasi yang peneliti lakukan didapatkan bahwa faktor individu yang berkontribusi untuk terjadinya bullying ini adalah individu yang cenderung memiliki kepribadian yang agresif, kurang empati serta memiliki kelebihan fisik dibanding korbannya. Hal ini sesuai dengan pendapat dari American Association of Administrators (2009); Heath dan Sheen (2005), yang mengidentifikasikan anak pelaku Bullying sebagai berikut : manipulatif, impulsif dan agresif; kurang berempati; secara fisik 
lebih kuat dari korbannya; kesulitan beradaptasi dengan aturan; harga diri tinggi; memiliki penilaian positif terhadap kekerasan; pencapaian nilai akademik yang rendah; berasal dari lingkungan keluarga yang keras; mengalami gejala-gejala depresi.

Dari faktor-faktor individu, teman sebaya dan lingkungan terlihat variabel yang paling besar pengaruhnya terhadap kejadian Bullying adalah faktor lingkungan dengan $\mathrm{P}$ Value 0,073 (OR = 4,092) dan dapat diartikan bahwa jika siswa SD terpapar faktor lingkungan yang beresiko Bullying sebanyak satu kali, maka siswa SD tersebut akan beresiko untuk berperilaku Bullying sebanyak 4 kali. Astuti (2008 dalam Rachmijati, 2015), mencirikan sekolah yang pada umumnya mudah terdapat kasus bullying yaitu : 1). Sekolah yang di dalamnya terdapat perilaku deskriminatif baik dikalangan guru maupun siswa; 2). Kurangnya pengawasan dan bimbingan etika dari para guru dan petugas sekolah; 3). Terdapat kesenjangan yang besar antara siswa yang kaya dan miskin; 4). Adanya pola kedisiplinan yang sangat kaku ataupun terlalu lemah; 5). Bimbingan yang tidak layak dan peraturan yang tidak konsisten.

\section{Kesimpulan}

Ada hubungan yang signifikan antara faktor individu, teman sebaya dan faktor lingungan dengan kejadian Bullying. Fartor lingkungan merupakan faktor yang paling berpengaruh terhadap kejadian bullying. Kerjasama antar elemen pendidikan yang meliputi guru-guru dan perangkat sekolah, keluarga, siswa sangat dibutuhkan dalam memutus rantai kekerasan, sehingga bullying tidak dianggap sebagai hal yang lumrah dan dilakukan pembiaran terhadap perilaku ini. Agar pengetahuan guru serta perangkat sekolah tentang bullying dapat ditingkatkan melalui seminar-seminar ataupun yang lainnya, sehingga bullying ini dapat dicegah.

\section{Daftar Pustaka}

1) Adilla, Nissa. (2009). Pengaruh Kontrol Sosial Terhadap Perilaku Bullying Pelajar Di Sekolah Menengah Pertama.
Jurnal Kriminologi Indonesia vol.5 No.I : 55-66. http://journal.ui.ac.id/index.php/jki/article/viewFile/12 $56 / 1161$

American As Sociation of School Administrators. 2009. Bullying at School and online. Education.com Holdings, Inc.

Dake, J.A., Price, J.H. \& Telljohann, S.K. (2003). The Nature and extent of bullying at school. The Journal of School Health, 73 (3): 173

Dewi, Dewa Ayu Putu Indah saraswati. (2014). Gambaran Kejadian Dan Karakteristik Bullying Pada Anak Usia Sekolah Dasar Wilayah Kerja Puskesmas I Pekutatan Kabupaten Jembrana Bali. ISSN: 2089-9084 ISM, VOL. 8 NO.1, JANUARI-MARET, HAL 1 . http://isainsmedis.id/ojs/

Diyantini, Yanti. Lismawati. 2015. Hubungan karakteristik dan kepribadian anak dengan Kejadian bullying pada siswa kelas V Di SD "X" di Kabupaten Badung. COPING Ners Journal ISSN: 2303-1298 Vol 3, No. 3 Edisi September-Desember 2015.

Latifah, Fika. 2012. Hubungan Karakteristik Anak Usia Sekolah dengan Kejadian Bullying di Sekolah Dasar di Bogor. Depok: Fakultas Ilmu Keperawatan UI

Magfirah, Ulfah \& Rachmawati, Mira Eliza. ( 2009). Hubungan antara iklim sekolah dengan kecenderungan perilaku bullying. http://setiabudi.ac.id/jurnalpsikologi/images/files/Jurna l\%201(1).pdf

Namie, Gary. 2014. WBI U.S. Workplace Bullying Survey. Workplace Bullying Institute.

National Crime Prevention Centre. (2008). Bullying Prevention : Nature and Extent of Bullying in Canada. Online, diunduh tanggal 24 Maret 2017

Ningrum, Anindita Widya, dkk (2015). Studi Tentang Perilaku Bullying Di Sekolah Menengah Pertama Se-Kecamatan Prajurit Kulon Kota Mojokerto Serta Penanganan Oleh Guru BK. Jurnalmahasiswa.unesa.ac.id/articel/pdf

Pratiwi., Puspita \& Rosalina. Hubungan Peran Teman Sebaya Dengan Perilaku Bullying Pada Anak Usia Sekolah Kelas 5 Dan 6 Di Sd Sriwedari 02 Kecamatan Jaken Kabupaten Pati. http://perpusnwu.web.id/karyailmiah/dokuments/4214.pd f 
Polit, D.F., \& Beck, C.T (2004). Nursing Research: principles and Methods (7th ed). Philadelphia: Lippincott Williams \& Wilkins

Purwanto, Edi. (2101). Alternatif Pemecahan Perilaku Bullying Pada Anak Sekolah Dasar. https://jendelapemikiran.wordpress.com/2010/12/01/a Iternatif-pemecahan-perilaku-bullying-pada-anak-sekola h-dasar/

Rachmijati, Cynantia. (2015). Bullying Dalam Dunia Pendidikan. Jurnal : Bullying Dalam Dunia Pendidikan.http://cynantia-rachmijati.dosen.stkipsiliwan gi.ac.id/2015/01/jurnal-bullying-dalam-dunia-pendidikan

Saifullah, Fitrian.(2016). Hubungan Antara Konsep Diri Dengan Bullying Pada Siswa-Siswi SMP. eJournal Psikologi, 2016, 4 (2): 200- 214 ISSN 2477-2674, ejournal.psikologi.fisip-unmul.ac.id (C) Copyright 2016

Setyawan, David. 2014. KPAI. Kasus Bullying dan Pendidikan Karakter. Online, diunduh tanggal 24 Maret 2017

Siswati \& Widayanti, Costrie Ganes.2009.Fenomena Bullying Di Sekolah Dasar Negeri Di Semarang: Sebuah studi deskriptif.

http://eprints.undip.ac.id/8336/1/fenomena_bullying_d i_sekolah_dasar_negeri_di_semarang.pdf

Soedjatmiko, dkk. (2013). Gambaran Bullying dan Hubungannya dengan Masalah Emosi dan Perilaku pada Anak Sekolah Dasar. Sari Pediatri, Vol. 15, No. 3, Oktober 2013. saripediatri.org/index.php/sari-pediatri/article/download/.

Wong, Donna L., et al. (2009). Buku Ajar Keperawatan Pediatrik, Ed. 6. Jakarta: EGC. 